\title{
The evolution from life insurance to financial engineering
}

\author{
Ralph S. J. Koijen ${ }^{1} \cdot$ Motohiro Yogo ${ }^{2}$
}

Received: 7 July 2021 / Accepted: 27 July 2021 / Published online: 20 August 2021

(c) International Association for the Study of Insurance Economics 2021

\begin{abstract}
Since the mid-1980s, the share of household net worth intermediated by US financial institutions has shifted from defined benefit plans to life insurers and defined contribution plans. Life insurers have primarily grown through variable annuities, which are mutual funds with longevity insurance, a potential tax advantage, and minimum return guarantees. The minimum return guarantees change the primary function of life insurers from traditional insurance to financial engineering. Variable annuity insurers are exposed to interest and equity risk mismatch and their stock returns were especially low during the COVID-19 crisis. We consider regulatory changes, such as more detailed financial disclosure and standardized stress tests, to monitor potential risk mismatch and to ensure stability of the insurance sector.
\end{abstract}

Keywords COVID-19 crisis · Global financial crisis · Life insurance industry · Minimum return guarantee · Variable annuity

JEL Classification G22 · G32

\footnotetext{
This invited paper was prepared for the Geneva Risk Economics Lecture at the 47th Seminar of European Group of Risk and Insurance Economists. We thank Alexander Mürmann, Gregory Niehaus, and Casey Rothschild for comments. A.M. Best Company, Morningstar, and the NAIC own the copyright to their respective data, which we use with permission under their license agreements with Princeton University. This paper is based upon work supported by the National Science Foundation under Grant 1727049. Koijen acknowledges financial support from the Center for Research in Security Prices at the University of Chicago and the Fama Research Fund at the University of Chicago Booth School of Business.
}

Motohiro Yogo

myogo@princeton.edu

1 University of Chicago, Chicago, USA

2 Princeton University, Princeton, USA 


\section{Introduction}

The business of life insurers and the associated risks have substantially changed over the last 20 years. The traditional sources of risk for life insurers are uncertainty in interest rates, aggregate longevity or mortality, and policyholder behavior. A nearly constant leverage ratio from 1945 through the 1990s suggests that life insurers managed these risks well for decades when fixed annuities and life insurance were their primary liabilities. Life insurers manage interest risk by investing a significant share of their assets in long-term bonds. They manage longevity or mortality risk by offsetting annuities with life insurance. Uncertainty in policyholder behavior may be more difficult to hedge, but life insurers have decades of experience to assess the policyholder risk of fixed annuities and life insurance. Finally, life insurers diversify these sources of risk through unaffiliated reinsurance.

As the share of household net worth intermediated by private defined benefit plans has declined since the 1980s, the share intermediated by life insurers and private defined contribution plans has grown. At the same time, the composition of life insurer liabilities has shifted from life insurance to variable annuities, which are mutual funds with longevity insurance and a potential tax advantage. Thus, variable annuities replace the key functions of defined benefit plans in individual accounts and employer-sponsored plans. Since the 2000s, life insurers have competed on variable annuities with minimum return guarantees, which are essentially long-maturity put options on the mutual fund.

The large size of the variable annuity market reflects its importance for household welfare. In theory, minimum return guarantees could facilitate efficient risk sharing across heterogeneous agents (Dumas 1989; Chan and Kogan 2002) or overlapping generations (Allen and Gale 1997; Ball and Mankiw 2007). Investors cannot easily replicate minimum return guarantees because traded options have shorter maturity and model uncertainty exposes investors to basis risk in a dynamic hedging program. Therefore, insurers complete a missing market for long-maturity options by offering minimum return guarantees over long horizons.

The minimum return guarantees change the primary function of life insurers from traditional insurance to financial engineering. Life insurers are exposed to interest risk because they have not sufficiently increased the maturity of their bond portfolio or used derivatives to offset the negative duration and the negative convexity from variable annuities. Life insurers are also exposed to long-run volatility risk, which is difficult to hedge with traded options that are short term. The presence of high leverage and risk mismatch makes life insurers similar to pension funds. However, the minimum return guarantees make life insurers different from pension funds because they are engineering complex payoffs over long horizons that are difficult to hedge with traded options.

During the global financial crisis, many insurers including Aegon, Allianz, AXA, Delaware Life, John Hancock, and Voya (formerly a US subsidiary of ING) suffered large increases in variable annuity reserves ranging from 27 to $125 \%$ of total equity. Hartford was bailed out by the Troubled Asset Relief Program in 
June 2009 because of significant losses on their variable annuity business. The risks associated with minimum return guarantees are not limited to the US. For example, Equitable Life in the UK failed partly because of guarantees that were too generous (Roberts 2012). Perhaps more relevant to the low interest environment, many Japanese life insurers experienced significant losses because of overly generous guarantees in the early 2000s (Kashyap 2002). Minimum return guarantees are important globally and represent a major share of life insurer liabilities in Austria, Denmark, France, Germany, the Netherlands, and Sweden (European Systemic Risk Board 2015; Hombert and Lyonnet 2017). In these countries, the average duration of liabilities exceed that of assets by 5 to 10 years (European Insurance and Occupational Pensions Authority 2014), which implies significant losses if interest rates remain unexpectedly low as they have been since the European sovereign debt crisis through 2020.

This survey paper primarily draws upon research in Koijen and Yogo (2021) and Koijen and Yogo (2022). Section 2 provides a historical perspective of life insurers' liabilities and leverage. Life insurers' leverage has become more volatile since the 1990s, suggesting greater risk mismatch due to the minimum return guarantees. Section 3 describes variable annuities and details about their regulation that are relevant for this paper. Section 4 shows that the top insurers suffered large increases in variable annuity reserves during the global financial crisis. Variable annuity insurers' stock returns have negative exposure to long-term bond returns after the global financial crisis, and their stock returns were especially low during the COVID-19 crisis. Section 5 shows that variable annuity sales decreased, fees increased, and many insurers stopped offering minimum return guarantees during the global financial crisis. As variable annuities shocked risk-based capital, they affected other important functions of life insurers including the pricing of fixed annuities and reinsurance. Section 6 considers regulatory changes, such as more detailed financial disclosure and standardized stress tests, to monitor potential risk mismatch and to ensure stability of the insurance sector.

\section{A historical perspective of life insurers}

We provide a historical perspective of life insurers' liabilities and leverage in comparison with property and casualty insurers, private pension funds, and banks. Since the 1980s, life insurers have grown significantly, and the composition of their liabilities has shifted from life insurance to variable annuities. Coinciding with the changing nature of their business, life insurers' leverage has become more volatile because of greater risk mismatch since the 1990s.

\subsection{Liabilities}

Life insurers are among the largest of financial institutions. Table 1 reports the liabilities of US financial institutions in 2017. Life insurers had \$6.5 trillion of 
Table 1 Liabilities of financial institutions in 2017

\begin{tabular}{ll}
\hline Sector & Trillion \$ \\
\hline Life insurance & 6.5 \\
Property \& casualty insurance & 1.2 \\
Private defined contribution & 6.2 \\
Private defined benefit & 3.2 \\
\hline
\end{tabular}

Authors' tabulation based on the Financial Accounts of the United States (Board of Governors of the Federal Reserve System 2017). See Appendix 1 for variable definitions

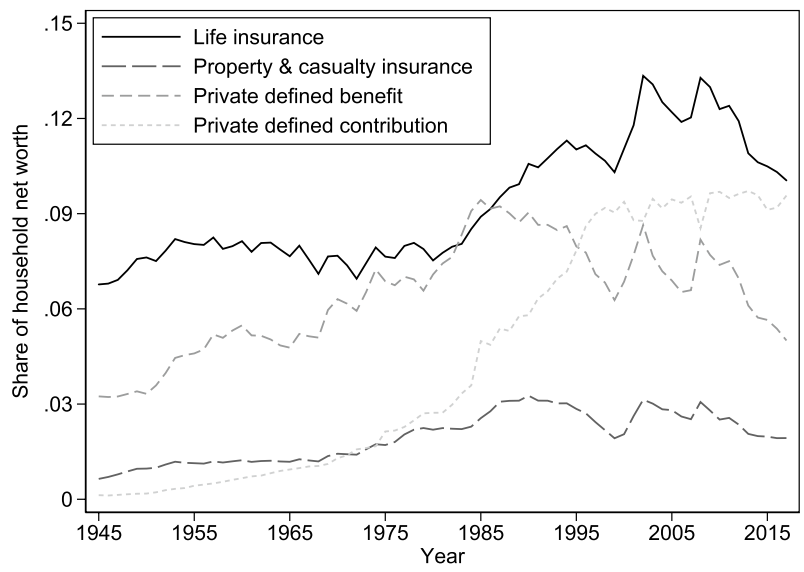

Fig. 1 Insurance and pension liabilities. Authors' tabulation based on the Financial Accounts of the United States for 1945 to 2017 (Board of Governors of the Federal Reserve System 2017). See Appendix 1 for variable definitions

liabilities, which is larger than property and casualty insurers, private defined contribution plans, and private defined benefit plans.

Figure 1 reports historical trends in the shares of US household net worth that are intermediated by insurers and pension funds. In 2017, life insurers accounted for $10.0 \%$ of household savings, which is higher than $9.6 \%$ for private defined contribution plans and $5.0 \%$ for private defined benefit plans. Property and casualty insurers accounted for $1.9 \%$ of household savings. Although property and casualty insurance is important for insuring idiosyncratic risk, it is not a large share of household savings because the policies typically have short maturities.

Private defined benefit plans peaked at $9.4 \%$ of household net worth in 1985 and fell thereafter. The fall of defined benefit plans is offset by the rise of life insurers and defined contribution plans. Private employers are shifting from defined benefit plans to defined contribution plans to avoid the risk of underfunded pensions. However, not all employers offer defined contribution plans, and some employees may not be eligible for pension benefits. In contrast, life insurers could play an important role in retirement savings, even for households without 
Table 2 Composition of life insurers' liabilities in 2017

\begin{tabular}{ll}
\hline Liability & Trillion \$ \\
\hline General account & \\
Life insurance & 1.2 \\
Annuities & 1.2 \\
Pension funds & 0.7 \\
Other (including accident \& health) & 0.8 \\
Separate account (variable annuities) & 2.7 \\
\hline
\end{tabular}

Authors' tabulation based on the Financial Accounts of the United States (Board of Governors of the Federal Reserve System 2017).

See Appendix 1 for variable definitions

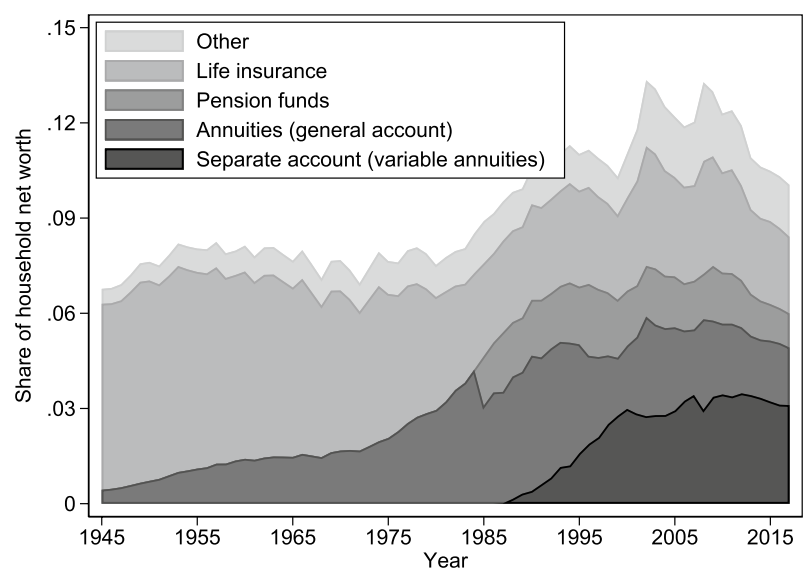

Fig. 2 Composition of life insurers' liabilities. Authors' tabulation based on the Financial Accounts of the United States for 1945 to 2017 (Board of Governors of the Federal Reserve System 2017). General account annuities include pension liabilities before 1985. See Appendix 1 for variable definitions

access to defined contribution plans. Households can hold annuities in defined contribution plans, individual retirement accounts, and non-retirement accounts.

Table 2 reports the composition of US life insurers' liabilities in 2017. Life insurance and annuities in the general account each accounted for $\$ 1.2$ trillion of liabilities. Life insurers manage some private pension funds, and these liabilities accounted for $\$ 0.7$ trillion. Other liabilities including accident and health insurance accounted for $\$ 0.8$ trillion.

Separate account liabilities, which are primarily variable annuities, accounted for $\$ 2.7$ trillion in 2017 . The mutual fund underlying a variable annuity is held in a separate account on behalf of investors, which is not subject to the insurer's default risk. The minimum return guarantee on the mutual fund is part of annuity liabilities in the general account. General account liabilities are subject to default risk because of risk mismatch with general account assets.

Figure 2 reports historical trends in the composition of US life insurers' liabilities, which are in shares of household net worth for comparison with Fig. 1. In 


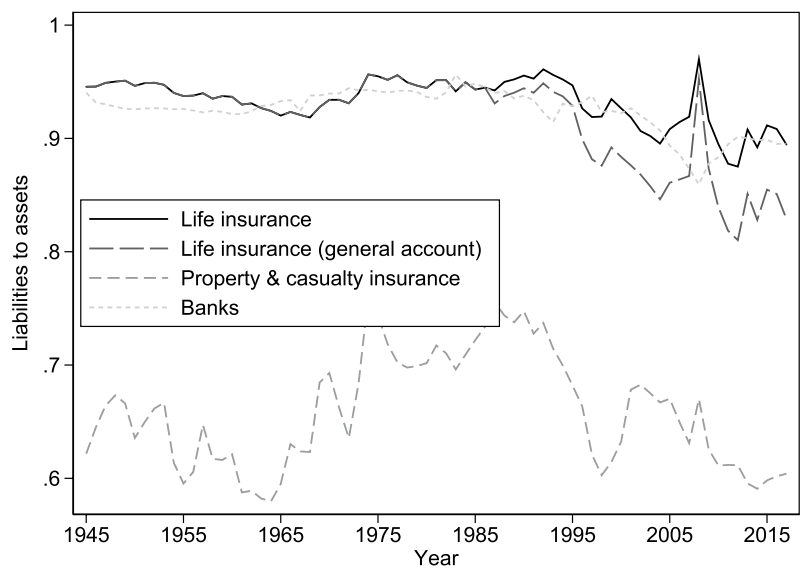

Fig. 3 Leverage of financial institutions. Authors' tabulation based on the Financial Accounts of the United States for 1945 to 2017 (Board of Governors of the Federal Reserve System 2017). See Appendix 1 for variable definitions

the early part of the sample before the 1980s, life insurance was larger than annuities. Since the 1990s, variable annuities have grown rapidly and are now the largest liability. In 2017, fixed and variable annuities together accounted for $4.9 \%$ of household net worth, which is about twice the size of $2.4 \%$ for life insurance. The label "life insurance companies" was appropriate back in 1945, but they should perhaps be relabeled "annuity and life insurance companies" in modern time. However, even the latter label does not do justice to the fact that the majority of their annuity business involves financial engineering of complex payoffs.

\subsection{Leverage}

Figure 3 reports historical trends in the leverage (i.e., the ratio of liabilities to assets) of US financial institutions. Interestingly, the leverage of life insurers and banks closely track each other at low frequency. They both hover around 95\% in the early part of the sample before 1990. Since then, the leverage of both life insurers and banks have gradually decreased to $90 \%$ in 2017 . During the global financial crisis, life insurers' leverage spiked up to $97 \%$, while banks' leverage spiked down to $86 \%$. Life insurers can afford to let leverage increase in response to a transitory shock to asset values because of the long-term nature of their liabilities that are generally not prone to runs.

Property and casualty insurers have always had lower and more volatile leverage than life insurers because of the less predictable nature of their liabilities. However, the shift from life insurance to variable annuities since the 1990s means that life insurers now have less predictable liabilities subject to risk mismatch. Coinciding with the changing nature of their business, life insurers' leverage has decreased and become more volatile since the 1990s. 


\section{Background on variable annuities}

We start with an example of an actual product to explain how variable annuities work. We then describe details about risk-based capital regulation for variable annuities. Finally, we summarize economic and institutional reasons why insurers do not fully hedge variable annuity risk.

\subsection{An example of a variable annuity}

A variable annuity is a mutual fund that is sold through an insurer with longevity insurance and a potential tax advantage. For an additional fee, insurers offer an optional minimum return guarantee on the mutual fund. Thus, a variable annuity with a minimum return guarantee is a retail financial product that packages a mutual fund with a long-maturity put option on the mutual fund. To explain how variable annuities work, we start with an example of an actual product.

MetLife Investors USA Insurance Company (2008) offers a variable annuity called MetLife Series VA, which comes with various investment options and guaranteed living benefits. In 2008:3, one of the investment options was the American Funds Growth Allocation Portfolio, which is a mutual fund with a target equity allocation of 70 to $85 \%$ and an annual portfolio expense of $1.01 \%$. One of the guaranteed living benefits was a Guaranteed Lifetime Withdrawal Benefit (GLWB). MetLife Series VA has an annual base contract expense of $1.3 \%$ of account value, and a GLWB has an annual fee of $0.5 \%$ of account value. Thus, the total annual fee for the variable annuity with a GLWB is $1.8 \%$, which is on top of the annual portfolio expense on the mutual fund.

To understand the GLWB, we first describe a standalone investment in the mutual fund and the withdrawals that it would enable for retirement income. Suppose that an investor were to invest in the American Funds Growth Allocation Portfolio in 2008:3. After 2013:3, the investor withdraws a constant dollar amount each year that is $5 \%$ of the highest account value ever reached. For example, this behavior describes an investor who invests in a mutual fund five years before retirement and subsequently spends down her wealth by consuming a constant dollar amount each year. Figure 4 shows the path of account value per $\$ 1$ of initial investment with the shaded region covering the withdrawal period after 2013:3. The account value fluctuates over time because of uncertainty in investment returns.

The same investor could purchase a GLWB from MetLife and guarantee her investment returns. A GLWB has an annual rollup rate of 5\% before first withdrawal, which means that at each contract anniversary, the guaranteed amount steps up to the greater of the account value and the previous guaranteed amount accumulated at 5\%. Thus, a GLWB is a put option on the mutual fund that locks in every year to a strike price that accumulates at an annual rate of 5\%. Figure 4 shows that the guaranteed amount can only increase during the five-year accumulation period, protecting the investor from downside risk in investment returns. 


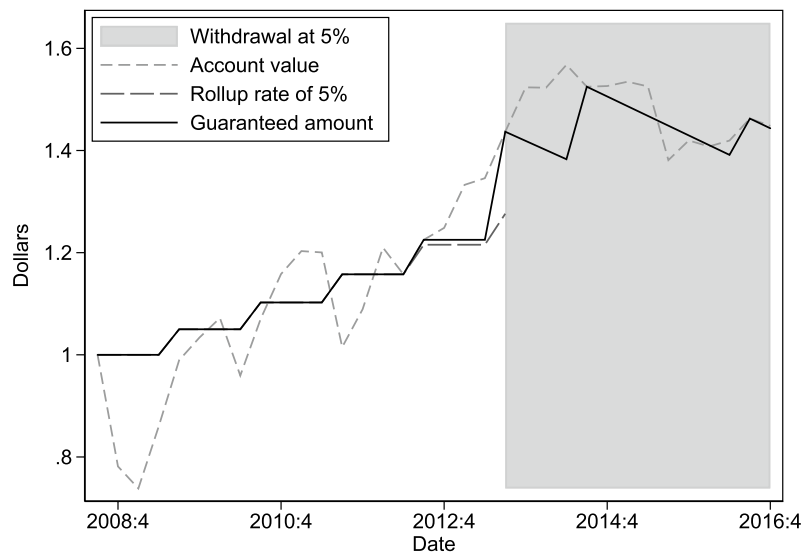

Fig. 4 An example of a guaranteed living withdrawal benefit. This example shows the evolution of account value and the guaranteed amount for MetLife Series VA with a GLWB from 2008:3 to 2016:4. The investment option is the American Funds Growth Allocation Portfolio. The investor is assumed to annually withdraw 5\% of the highest guaranteed amount after 2013:3. For simplicity, this example abstracts from the impact of fees on account value and the guaranteed amount

From the insurer's perspective, the financial engineering of complex payoffs could lead to risk mismatch relative to the rest of its balance sheet.

Once the investor enters the withdrawal period, she can annually withdraw up to $5 \%$ of the highest guaranteed amount ever reached. In our example, the guaranteed amount in 2013:3 is $\$ 1.44$, which means that the investor can withdraw up to $\$ 1.44 \times 0.05=\$ 0.072$ per year. Each withdrawal gets deducted from both the account value and the guaranteed amount. A GLWB is a lifetime guarantee in that the investor receives income (i.e., $\$ 0.072$ per year) as long as she lives, even after the account is depleted to zero. During the withdrawal period, the guaranteed amount steps up to the account value at each contract anniversary. In Fig. 4, these step-ups occur in 2014:3 and 2016:3 because of high investment returns.

A GLWB is the most common type of guaranteed living benefit. The other three types of guaranteed living benefits are a Guaranteed Minimum Withdrawal Benefit (GMWB), a Guaranteed Minimum Income Benefit (GMIB), and a Guaranteed Minimum Accumulation Benefit (GMAB). A GMWB is similar to a GLWB, except that the investor does not receive income after the account is depleted to zero. A GMIB is similar to a GLWB, except that guaranteed amount at the beginning of the withdrawal period converts to a life annuity (i.e., fixed income for life). A GMAB provides a minimum return guarantee much like the accumulation period of a GLWB, but it does not have a withdrawal period with guaranteed income.

\subsection{Risk-based capital regulation}

Variable annuity liabilities enter both reserves and required capital in risk-based capital: 


$$
\mathrm{RBC}=\frac{\text { Assets }- \text { Reserves }}{\text { Required capital }} .
$$

As summarized in Junus and Motiwalla (2009), Actuarial Guideline 43 since December 2009 determines the reserve value of variable annuities, and the C-3 Phase II regulatory standard since December 2005 determines the contribution of variable annuities to required capital. Actuarial Guideline 43 is a higher reserve requirement than its precursor Actuarial Guideline 39, so insurers were given a phase-in period until December 2012 to fully comply with the new requirement.

To compute reserves and required capital, insurance regulators provide various scenarios for the joint path of Treasury, corporate bond, and equity prices. Insurers simulate the path of equity deficiency for their variable annuity business (net of the hedging programs and reinsurance) under each scenario and keep the highest present value of equity deficiency along each path. Insurers then compute reserves as a conditional mean over the upper 30\% of equity deficiencies (called CTE 70). This conditional tail expectation builds in a degree of conservatism that is conceptually similar to a correction for risk premia, but reserves do not coincide with the market value of liabilities. Insurers use the same methodology for required capital, except that they compute a conditional mean over the upper $10 \%$ of equity deficiencies (called CTE 90).

More generous guarantees with higher rollup rates or better coverage of downside market risk relative to fees require higher reserves and more capital. Moreover, minimum return guarantees are long-maturity put options on mutual funds whose value increases when the stock market falls, interest rates fall, or volatility rises. Therefore, both reserves and required capital increase in an adverse scenario like the global financial crisis, which puts downward pressure on risk-based capital.

Generally accepted accounting principles (GAAP) allow insurers to record variable annuity reserves at market value in contrast to the conditional tail expectation under Actuarial Guideline 43. Therefore, variable annuity reserves under the statutory accounting principles could increase relative to those under GAAP after a period of high volatility (Credit Suisse 2012). Moreover, an insurer that implements a hedging program under GAAP capital could actually increase the volatility of accounting equity under the statutory accounting principles. For these reasons, insurers have an incentive for captive reinsurance of variable annuities either to increase risk-based capital or to implement a hedging program under GAAP capital.

\subsection{Hedging of variable annuities}

Insurers could use derivatives to hedge interest and equity risk mismatch between their general account asset and liabilities, including the minimum return guarantees on variable annuities. US life insurers held $\$ 1.1$ trillion in notional amount of overthe-counter derivatives in 2014 (Berends and King 2015). Although this amount is a non-trivial share of their liabilities, insurers do not fully hedge for various economic and institutional reasons.

Insurers may not be able to fully hedge because the minimum return guarantees have longer maturities than traded options, which is central to their financial 
engineering challenge. Insurers are exposed to unexpected changes in implied volatility if they attempt to hedge the minimum return guarantees by rolling over shorter maturity options. A dynamic hedging program would be subject to basis risk because of model uncertainty, especially regarding long-run volatility (Sun 2009; Sun et al. 2009). In addition to basis risk, derivatives could expose insurers to counterparty risk. Although collateral could reduce counterparty risk, it increases the cost of the hedging programs (Berends and King 2015). A deeper economic question is why the market for long-maturity options is incomplete if insurers would want to hedge such risks. A potential reason is that someone must bear aggregate risk by market clearing, and insurers may have comparative advantage over other types of institutions because their liabilities have a longer maturity and are less vulnerable to runs (Paulson et al. 2012).

Insurers, especially stock rather than mutual companies, may not want to hedge because of risk-shifting motives that arise from limited liability and state guaranty associations (Lee et al. 1997). Another reason that insurers may not want to hedge is that existing regulation does not properly reward hedging of market value. Insurers report accounting equity under the statutory accounting principles at the operating company level and under GAAP at the holding company level. Therefore, hedge positions differ depending on whether the insurer targets economic, statutory, or GAAP capital. A hedging program that smoothes market equity could actually increase the volatility of accounting equity under the statutory accounting principles or GAAP (Credit Suisse 2012).

Whether insurers target market or accounting equity depends on whether the more important friction is economic (e.g., value-at-risk constraint) or regulatory (i.e., risk-based capital constraint). Sen (2019) uses a difference-in-difference identification strategy around the adoption of Actuarial Guideline 43 to show that insurers target accounting equity. Under the new regulation, the statutory accounting values of GMWB and GMAB became more sensitive to interest rates, while the statutory accounting value of GMIB remained insensitive. Insurers that primarily sold risk-sensitive products increased hedging under the new regulation. In contrast, insurers that primarily sold risk-insensitive products did not increase hedging and instead used captive reinsurance to reduce regulatory frictions.

\section{Evidence on risk mismatch}

We show that the top insurers suffered large increases in variable annuity reserves during the global financial crisis. We then show that variable annuity insurers' stock returns have negative exposure to long-term bond returns after the global financial crisis and that their stock returns were especially low during the COVID19 crisis. In the cross section of variable annuity insurers, the stock returns are highly correlated between the global financial crisis and the COVID-19 crisis, highlighting the persistent fragility that arises from the long-term nature of minimum return guarantees. 
Table 3 Summary of the variable annuity market

\begin{tabular}{|c|c|c|c|c|}
\hline \multirow[t]{2}{*}{ Year } & \multicolumn{2}{|c|}{ VA liabilities } & \multirow{2}{*}{$\begin{array}{l}\text { Number of } \\
\text { insurers }\end{array}$} & \multirow{2}{*}{$\begin{array}{l}\text { Reserve } \\
\text { valuation } \\
(\%)\end{array}$} \\
\hline & Billion \$ & $\begin{array}{l}\% \text { of total } \\
\text { liabilities }\end{array}$ & & \\
\hline 2005 & 1071 & 35 & 45 & 0.9 \\
\hline 2006 & 1276 & 38 & 47 & 0.8 \\
\hline 2007 & 1435 & 41 & 46 & 0.8 \\
\hline 2008 & 1068 & 34 & 44 & 4.1 \\
\hline 2009 & 1195 & 35 & 43 & 3.4 \\
\hline 2010 & 1344 & 36 & 43 & 2.5 \\
\hline 2011 & 1358 & 35 & 42 & 4.9 \\
\hline 2012 & 1434 & 36 & 39 & 3.9 \\
\hline 2013 & 1606 & 37 & 40 & 1.8 \\
\hline 2014 & 1599 & 37 & 38 & 2.3 \\
\hline 2015 & 1499 & 35 & 38 & 2.9 \\
\hline
\end{tabular}

Copyright American Finance Association; reprint of Koijen and Yogo (2021, table 2) with permission. Variable annuity liabilities are total related account value plus gross amount of variable annuity reserves minus reinsurance reserve credit on variable annuities. The reserve valuation is the ratio of gross amount of variable annuity reserves to total related account value.

\subsection{Variable annuity insurers}

Table 3 summarizes the variable annuity market. In 2005, variable annuity liabilities across all insurers were $\$ 1.071$ trillion or $35 \%$ of total liabilities. Variable annuity liabilities have ranged from 34 to $41 \%$ of total liabilities as their value fluctuates with the market value of the mutual funds. In 2015, variable annuity liabilities were $\$ 1.499$ trillion or $35 \%$ of total liabilities. The variable annuity market is fairly concentrated as measured by the number of insurers. The total number of insurers decreased from 44 in 2008 to 38 in 2015.

The reserve valuation (i.e., the ratio of gross amount of variable annuity reserves to total related account value) measures the value of the minimum return guarantees per dollar of underlying mutual funds. Table 3 shows that the reserve valuation aggregated across all insurers increased sharply from 0.8 in 2007 to $4.1 \%$ in 2008 . Since 2008 , the reserve valuation is volatile and remains high relative to the level before the global financial crisis.

Table 4 reports the top insurers ranked by their variable annuity liabilities in 2007. Eight of these insurers (Aegon, Allianz, AXA, Delaware Life, Hartford, Jackson National, Metropolitan Life, and Voya) suffered large increases in the reserve valuation ranging from 2.9 to 7.6 percentage points. These increases in the reserve valuation are significant shocks because these insurers have high leverage (i.e., the ratio of total liabilities to total assets) that range from 92 to $97 \%$. For five of the eight insurers, the increases in variable annuity reserves are a significant share of total equity, ranging from 29 to $125 \%$. 
Table 4 Top insurers by variable annuity liabilities

\begin{tabular}{|c|c|c|c|}
\hline \multirow[t]{2}{*}{ Insurer } & \multirow{2}{*}{$\begin{array}{l}\text { VA liabilities } \\
\text { in } 2007 \\
\text { (billion \$) }\end{array}$} & \multicolumn{2}{|c|}{ Change from 2007 to 2008} \\
\hline & & $\begin{array}{l}\text { Reserve valu- } \\
\text { ation }(\%)\end{array}$ & $\begin{array}{l}\text { Reserves (\% } \\
\text { of equity) }\end{array}$ \\
\hline AXA & 140 & 7.6 & 125 \\
\hline Metropolitan life & 129 & 2.9 & 6 \\
\hline Prudential & 122 & 1.4 & 13 \\
\hline Voya & 121 & 4.2 & 42 \\
\hline Hartford & 120 & 2.9 & 13 \\
\hline AIG & 99 & 0.8 & 2 \\
\hline Lincoln & 97 & 1.3 & 15 \\
\hline John Hancock & 95 & 1.8 & 27 \\
\hline Ameriprise & 81 & 1.0 & 13 \\
\hline Aegon & 63 & 7.3 & 29 \\
\hline Pacific life & 56 & 1.5 & 13 \\
\hline Nationwide & 46 & 1.7 & 18 \\
\hline Jackson National & 33 & 3.6 & 13 \\
\hline Delaware life & 24 & 3.7 & 44 \\
\hline Allianz & 23 & 5.3 & 35 \\
\hline New York life & 19 & 2.2 & 2 \\
\hline Genworth & 17 & 0.5 & 1 \\
\hline Northwestern & 12 & 0.2 & 0 \\
\hline Ohio National Life & 11 & 2.2 & 22 \\
\hline Fidelity investments & 10 & 1.0 & 8 \\
\hline Security benefit & 10 & 1.3 & 12 \\
\hline MassMutual & 6 & 1.7 & 0 \\
\hline Thrivent financial & 3 & 0.4 & 0 \\
\hline
\end{tabular}

Copyright American Finance Association; reprint of Koijen and Yogo (2021, table 3) with permission. Variable annuity liabilities are total related account value plus gross amount of variable annuity reserves minus reinsurance reserve credit on variable annuities. The reserve valuation is the ratio of gross amount of variable annuity reserves to total related account value. The change in gross amount of variable annuity reserves is reported as a share of total equity in 2007. The sample includes all insurers with at least $\$ 1$ billion of variable annuity sales in 2007

\subsection{Interest risk}

If the minimum return guarantees have higher duration and higher convexity than the general account assets, the overall balance sheet is potentially exposed to interest risk. The market value of equity decreases with unexpected decreases in interest rates, especially when the level of interest rates is low. Consistent with this hypothesis, Hartley et al. (2017) find that US life insurers' stock returns have significantly negative exposures to long-term bond returns in the prolonged period of low interest rates after the global financial crisis. In contrast, property and casualty insurers and 
Table 5 Risk exposure of variable annuity insurers

\begin{tabular}{lllll}
\hline Factor & \multicolumn{4}{l}{ By subsample } \\
\cline { 2 - 5 } & & \multicolumn{1}{l}{$1999-2007$} & $2008-2009$ & $2010-2017$ \\
\hline Stock market return & 1.36 & 0.56 & 2.56 & 1.11 \\
& $(0.19)$ & $(0.15)$ & $(0.22)$ & $(0.08)$ \\
10-year bond return & -0.01 & -0.38 & 1.14 & -1.28 \\
& $(0.32)$ & $(0.29)$ & $(0.66)$ & $(0.16)$ \\
Alpha (\%) & -0.22 & 0.35 & -1.14 & 0.41 \\
& $(0.46)$ & $(0.47)$ & $(1.70)$ & $(0.29)$ \\
Observations & 228 & 108 & 24 & 96
\end{tabular}

Copyright American Finance Association; reprint of Koijen and Yogo (2021, table 1) with permission. We construct monthly returns on a value-weighted portfolio of publicly traded US variable annuity insurers, which are listed in Koijen and Yogo (2021, appendix B). This table reports the betas and monthly alpha from a factor regression of excess portfolio returns, relative to the 1-month T-bill rate, on excess stock market returns and excess 10-year Treasury bond returns. Heteroscedasticity-robust standard errors are reported in parentheses. The sample period is January 1999 through December 2017

UK life insurers (that do not have variable annuities) do not have such exposure to interest rates.

In Koijen and Yogo (2021), we update the finding in Hartley et al. (2017) with a longer sample. We construct monthly returns on a value-weighted portfolio of publicly traded US variable annuity insurers. We regress excess portfolio returns, relative to the 1-month T-bill rate, on excess stock market returns and excess 10-year Treasury bond returns. Table 5 reports the betas and the monthly alpha from the factor regression.

Over the sample period from January 1999 to December 2017, the stock market beta is 1.36 , and the 10 -year bond return beta is -0.01 and statistically insignificant. On average, insurers do not have significant exposure to interest risk, controlling for exposure to the overall stock market. However, the 10-year bond return beta varies over time when we break the sample into three periods: pre-crisis (1999-2007), financial crisis (2008-2009), and post-crisis (2010-2017). In the post-crisis subsample, the 10 -year bond return beta is -1.28 with a $t$-statistic greater than 7 . That is, unexpected decreases in interest rates are bad news for insurers during this prolonged period of low interest rates. A coefficient near -1 implies that the negative duration gap is close to the duration of the 10-year Treasury bond.

\subsection{Stock returns during the COVID-19 crisis}

The COVID-19 crisis has again exposed the fragility of variable annuity insurers. We compare the drawdown, which is the maximum fall in the cumulative stock return, from January 2 to April 2, 2020. As reported in Panel A of Fig. 5, the 

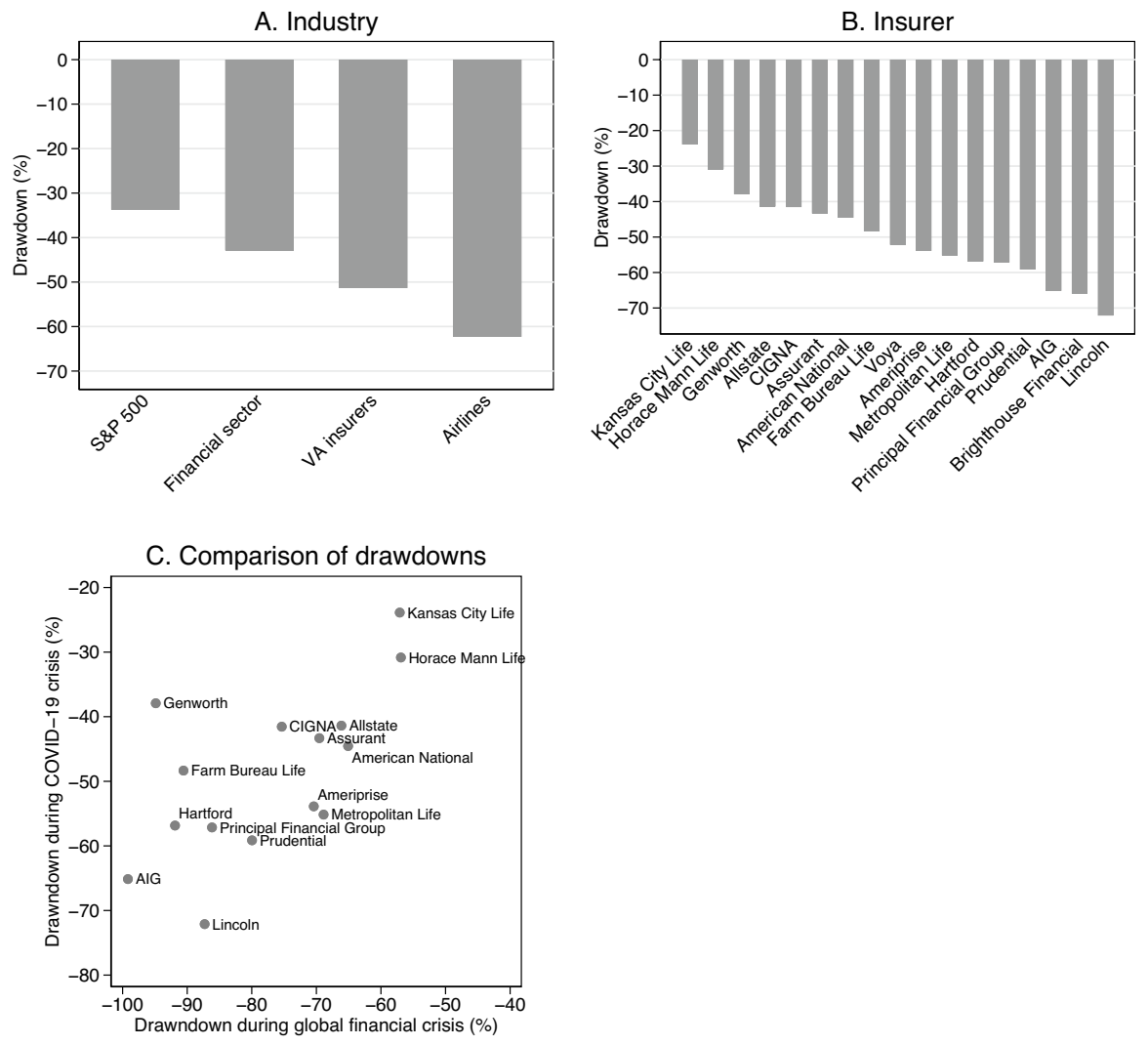

Fig. 5 Stock returns during the COVID-19 Crisis. Panel A reports the drawdowns on the S\&P 500 index, the Financial Select Sector SPDR Fund, a value-weighted portfolio of US variable annuity insurers, and the US Global Jets ETF. Panel B reports the drawdowns on individual insurers that make up the portfolio in Panel A. Panel C compares the drawdown during the COVID-19 crisis with the drawdown during the global financial crisis. The drawdown during the COVID-19 crisis is based on stock returns from January 2 to April 2, 2020. The drawdown during the global financial crisis is based on stock returns from January 2, 2008 to June 30, 2009

drawdown on a value-weighted portfolio of US variable annuity insurers was $-51 \%$ during this period. ${ }^{1}$ This drawdown was substantially larger than $-34 \%$ for the S\&P 500 index and $-43 \%$ for the Financial Select Sector SPDR Fund, which is the subset of financial sector stocks in the S\&P 500 index. In fact, the drawdown on variable annuity insurers was only slightly smaller than $-62 \%$ for the US Global Jets ETF, which tracks the US airline industry. Panel B of Fig. 5 reports the drawdowns on

\footnotetext{
1 We compute the portfolio return as a buy-and-hold portfolio with fixed weights at December 31, 2019. Otherwise, a continuously rebalanced portfolio would imply decreasing weights for insurers that had the lowest returns, even though the market value of their liabilities presumably increased.
} 


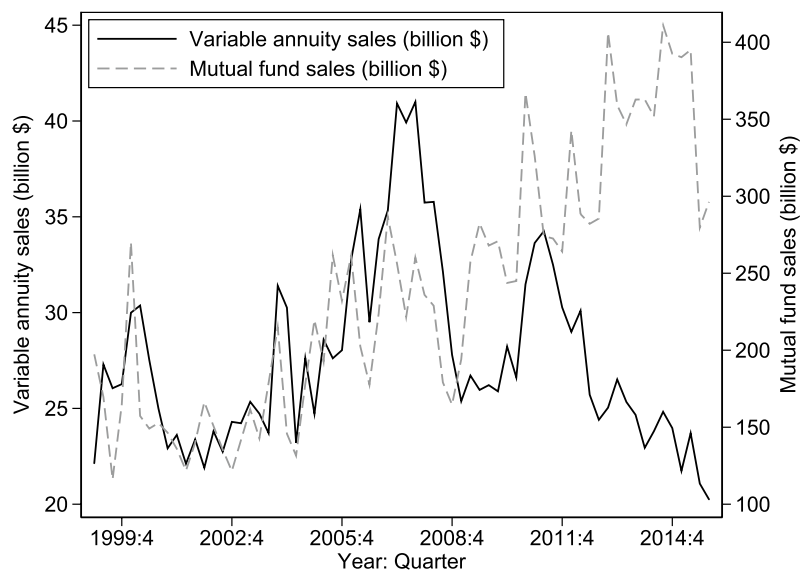

Fig. 6 Variable annuity sales. Copyright American Finance Association; reprint of Koijen and Yogo (2021, figure 3) with permission. The left axis reports quarterly sales of variable annuities across all contracts from 1999:1 to 2015:4. The right axis reports the aggregate sales of US open-end stock and bond mutual funds (excluding money market funds and funds of funds)

individual insurers that make up the portfolio in Panel A. AIG, Brighthouse Financial, and Lincoln National suffered the largest drawdowns exceeding $-65 \%$.

The top nine insurers with the largest variable annuity liabilities in Table 4 coincide almost perfectly with the top nine insurers that suffered the largest drawdowns in Fig. 5. AXA and John Hancock (part of Manulife Financial) in Table 4 are foreign insurers that are not part of Fig. 5, which focuses on US insurers. Brighthouse Financial was spun off from Metropolitan Life in 2017, so it was part of Metropolitan Life at the time of Table 4 in 2007. Therefore, Principal Financial Group is the only insurer that breaks the otherwise perfect correspondence of the top nine between Table 4 and Fig. 5. The long maturity of the minimum return guarantees means that variable annuities continue to be an important source of risk for life insurers.

Panel $\mathrm{C}$ of Fig. 5 compares the drawdowns during the COVID-19 crisis and the global financial crisis across insurers. Insurers with large variable annuity liabilities that had low stock returns during the global financial crisis also have low stock returns during the COVID-19 crisis. This persistent fragility highlights the longterm nature of minimum return guarantees and their high exposure to equity risk.

\section{Consequences of risk mismatch}

We show that variable annuity sales decreased, fees increased, and many insurers stopped offering minimum return guarantees during the global financial crisis. As variable annuities shocked risk-based capital, they affected other important functions of life insurers including reinsurance and the pricing of fixed annuities. 

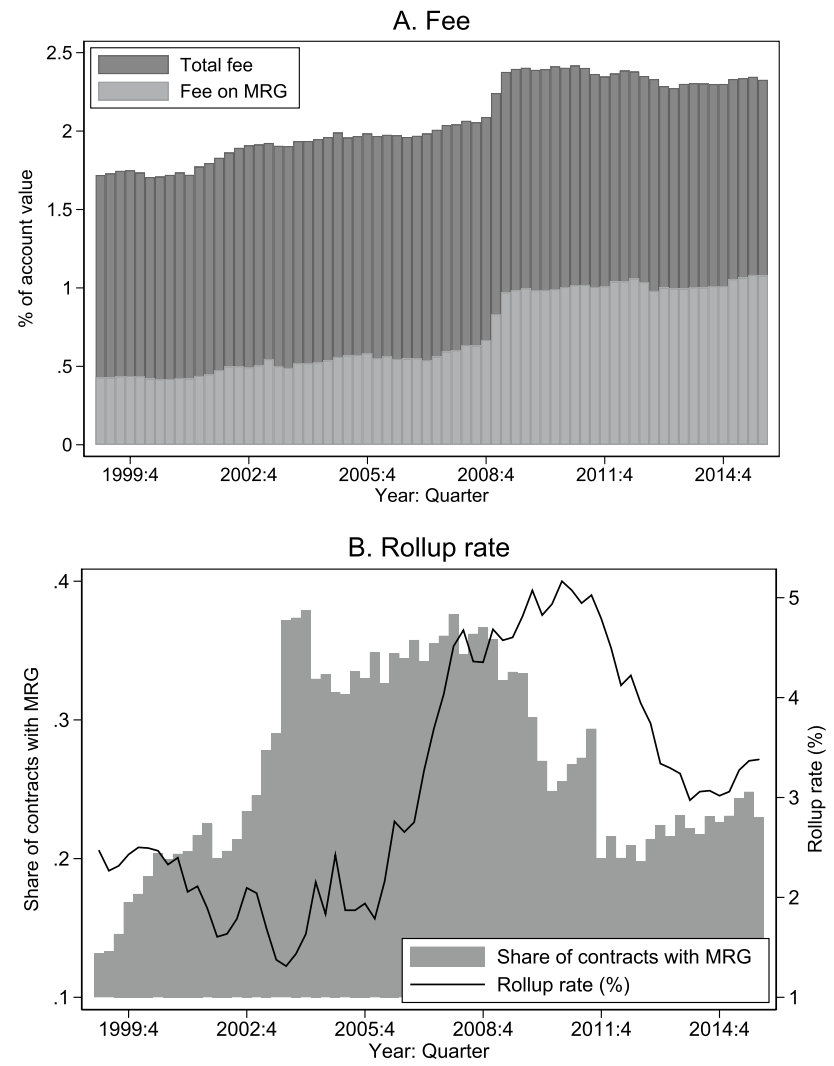

Fig. 7 Fees and rollup rates on minimum return guarantees. Copyright American Finance Association; reprint of Koijen and Yogo (2021, figure 5) with permission. Panel A reports the annual fee on open minimum return guarantees, averaged across contracts with sales weighting. The total annual fee includes the base contract expense. Panel B reports the rollup rate on open minimum return guarantees, averaged across contracts with sales weighting, and the share of contracts with minimum return guarantees. The sample includes all contracts with minimum return guarantees from 1999:1 to 2015:4

\subsection{Variable annuity market}

Figure 6 reports quarterly sales of variable annuities across all contracts from 1999:1 to 2015:4. Sales grew robustly from $\$ 22$ billion in $2005: 1$ to its peak at $\$ 41$ billion in 2007:4. Sales subsequently decreased during the global financial crisis to \$27 billion in 2009:2, picked up again to \$34 billion in 2011:2, and were \$20 billion in 2015:4. For comparison, the same figure shows the aggregate sales of US open-end stock and bond mutual funds (excluding money market funds and funds of funds), which is a larger market and shown on a different scale. Interestingly, sales of variable annuities and mutual funds moved closely together through 2008 , but the two time series diverge thereafter as mutual fund sales grew.

Panel A of Fig. 7 reports the average annual fee on open (for sale) minimum return guarantees from 1999:1 to 2015:4. The increase in fees during the global 
financial crisis coincides with the decrease in sales, suggesting an important role for a supply shock. The average annual fee on minimum return guarantees increased from $0.59 \%$ of account value in $2007: 4$ to $0.97 \%$ in $2009: 2$. Including the base contract expense, the total annual fee increased from $2.04 \%$ in $2007: 4$ to $2.38 \%$ in 2009:2. Since then, fees have remained stable. The average annual fee on minimum return guarantees was $1.08 \%$ (2.33\% including the base contract expense) in 2015:4.

Panel B of Fig. 7 summarizes the rollup rates on open contracts from 1999:1 to 2015:4. Conditional on offering a minimum return guarantee, the average rollup rate increased from $2.4 \%$ in $2005: 1$ to $4.0 \%$ in $2007: 4$, coinciding with the period of robust sales growth. The average rollup rate remained high through the global financial crisis and decreased only after 2011. However, the share of contracts with minimum return guarantees decreased after the global financial crisis from $36 \%$ in 2007:4 to $20 \%$ in 2011:4. That is, many insurers responded to the global financial crisis through the extensive margin by not offering contracts with minimum return guarantees, instead of the intensive margin of lowering rollup rates.

Depending on the contract characteristics of existing liabilities, different insurers experienced different shocks to the reserve valuation during the global financial crisis. Insurers that sold more generous guarantees before the global financial crisis suffered larger increases in the reserve valuation than those that sold less generous guarantees. Moreover, insurers that sold more generous guarantees could have made risk management more conservative after the global financial crisis as they learned that model uncertainty is higher than previously recognized. Thus, changes in the reserve valuation should be negatively related to sales growth in the cross section of insurers.

Panel A of Fig. 8 is a scatter plot of sales growth versus the change in the reserve valuation from 2007 to 2010 . The linear regression line shows that sales growth is negatively related to the change in the reserve valuation. On the bottom right are insurers like AXA and Genworth that essentially closed their variable annuity business as they suffered large increases in the reserve valuation. On the left side are six insurers (Fidelity Investments, MassMutual, New York Life, Northwestern, Ohio National, and Thrivent Financial) that did not offer a GLWB in 2007, which tends to be the most generous guarantee among guaranteed living benefits. The reserve valuation did not change much for these insurers because they sold less generous guarantees.

In Koijen and Yogo (2021), we explain this evidence with a model of insurance markets in which financial frictions and market power are important determinants of pricing, contract characteristics, and the degree of market completeness. Insurers compete in an oligopolistic market by setting the fee and the rollup rate. Required capital increases in the rollup rate because of a risk-based capital or an economic risk constraint. An adverse shock to the valuation of existing liabilities increases the shadow cost of capital and drives up the marginal cost of issuing contracts. The insurer not only raises the fee but lowers the rollup rate to reduce risk exposure. When the shadow cost of capital is sufficiently high, the insurer stops offering minimum return guarantees to avoid additional risk exposure. 


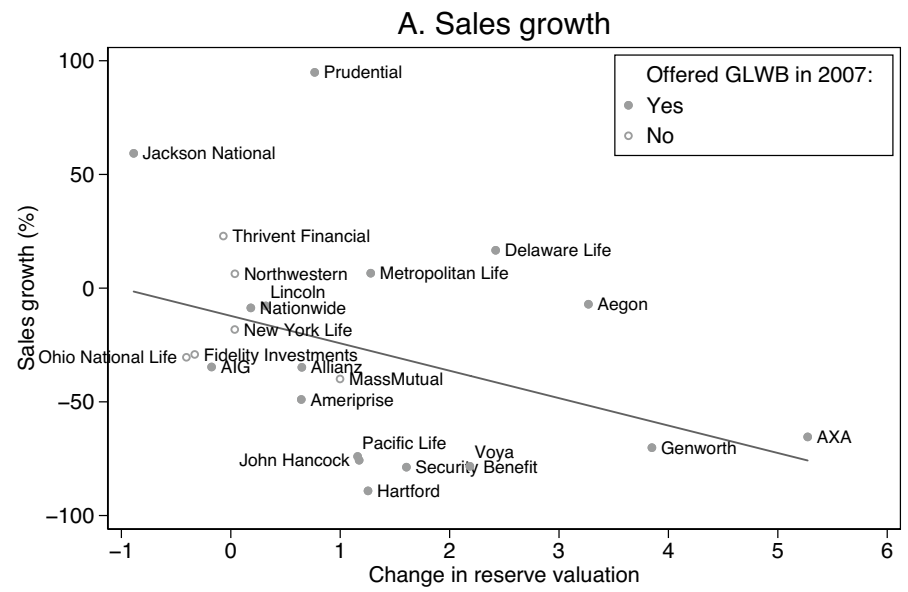

B. Variable annuity reinsurance

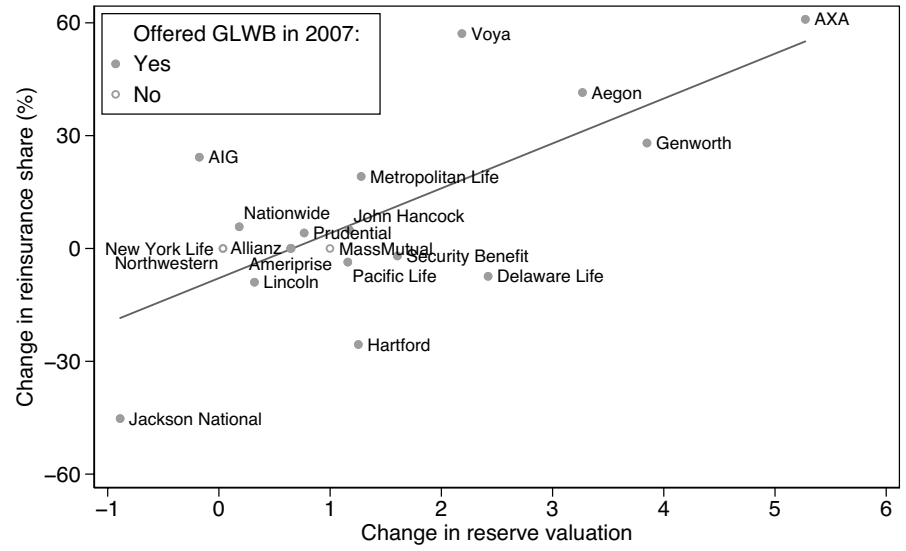

Fig. 8 Cross section of insurers during the global financial crisis. Copyright American Finance Association; reprint of Koijen and Yogo (2021, figure 6) with permission. Panel A is a scatter plot of sales growth versus the change in the reserve valuation from 2007 to 2010 . Panel B is a scatter plot of the change in the reinsurance share of variable annuities versus the change in the reserve valuation from 2007 to 2010 . Both panels report a linear regression line through the scatter points. The sample includes all insurers with at least $\$ 1$ billion of variable annuity sales in 2007

\subsection{Reinsurance}

As we discussed in Section 3, variable annuity reserves under the statutory accounting principles increase relative to those under GAAP after a period of high volatility. If insurers that suffered large increases in the reserve valuation were constrained, they have an incentive to move variable annuity reserves off balance sheet through reinsurance. Panel B of Fig. 8 is a scatter plot of the change in the reinsurance share of variable annuities versus the change in the reserve valuation from 2007 to 2010. The linear regression line shows that the change in the reinsurance share of variable 
annuities is positively related to the change in the reserve valuation. On the top right are insurers like AXA and Genworth that increased the reinsurance share of variable annuities as they suffered large increases in the valuation. This evidence suggests an important role for a risk-based capital constraint rather than an economic risk constraint.

\subsection{Pricing of fixed annuities}

Koijen and Yogo (2015) find that insurers lowered fixed annuity and life insurance prices from November 2008 to February 2009, when falling interest rates implied that they should have instead raised prices. The average markup, relative to actuarial value, was $-16 \%$ for 30 -year term annuities and $-19 \%$ for life annuities at age 60 . Similarly, the average markup was $-57 \%$ for universal life insurance at age 30 . This extraordinary pricing behavior was a consequence of two unusual circumstances. First, the global financial crisis had an adverse impact on insurers' balance sheets, especially those insurers with variable annuity liabilities. Second, statutory reserve regulation allowed insurers to record far less than a dollar of reserve per dollar of economic liability around December 2008. Thus, insurers could generate accounting profits by selling policies at a price far below actuarial value as long as that price was above the reserve value.

In the cross section of insurers, the price reductions were larger for those insurers that suffered larger balance sheet shocks. Figure 9 shows the cross-sectional relation between changes in annuity prices from May 2007 to November 2008 and four measures of balance sheet shocks at fiscal year-end 2008. The figure reveals two interesting facts. First, most of the insurers lowered prices during this period, which is remarkable given that falling interest rates implied rising actuarial values. Second, the price reductions were larger for those insurers with lower asset growth, higher leverage ratio, lower risk-based capital relative to guideline, and higher ratio of deferred annuity liabilities to equity. Deferred annuities include fixed and variable annuities, whose minimum return guarantees were unprofitable during the global financial crisis.

Koijen and Yogo (2015) rule out default risk as an alternative explanation for several reasons. First, the markups on term annuities are too low to be justified by default risk, given reasonable assumptions about the recovery rate. Second, the term structure of risk-neutral default probabilities implied by term annuities does not match that implied by credit default swaps in magnitude, slope across maturity, or variation across insurers. Finally, the absence of discounts on life annuities during the Great Depression serves as out-of-sample evidence against default risk as a sole explanation. 


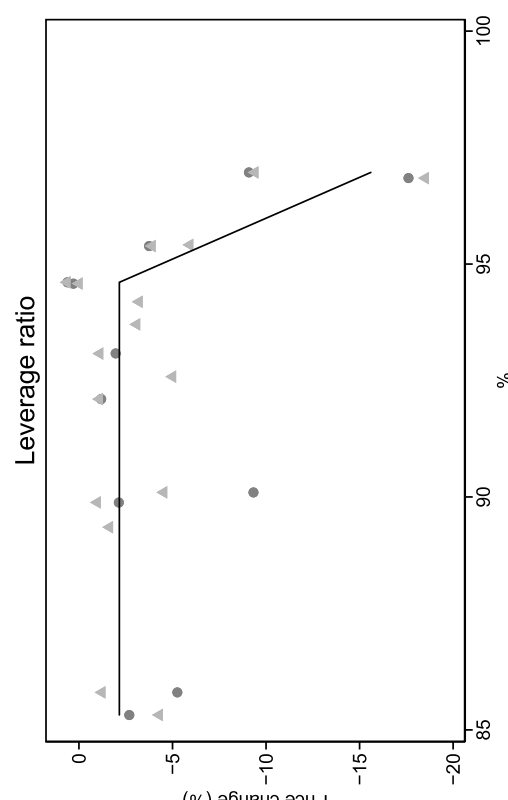

(\%) әбиецว әว!بd

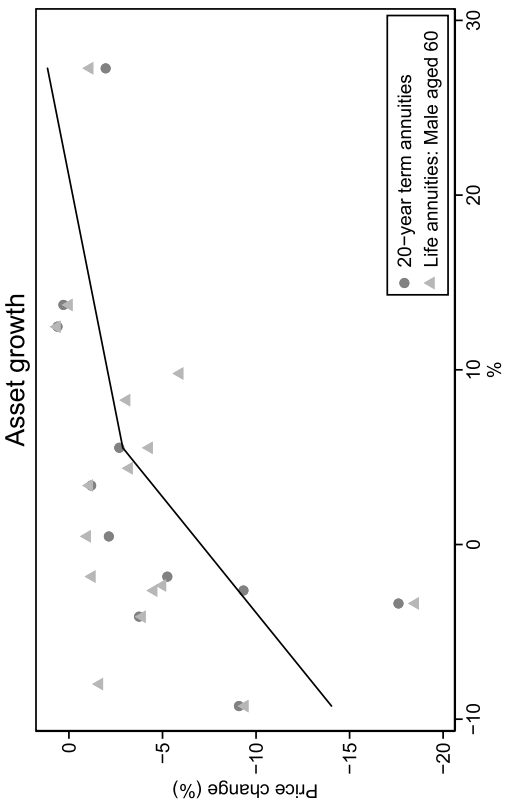

(\%) әбиечо әэ!ฺd

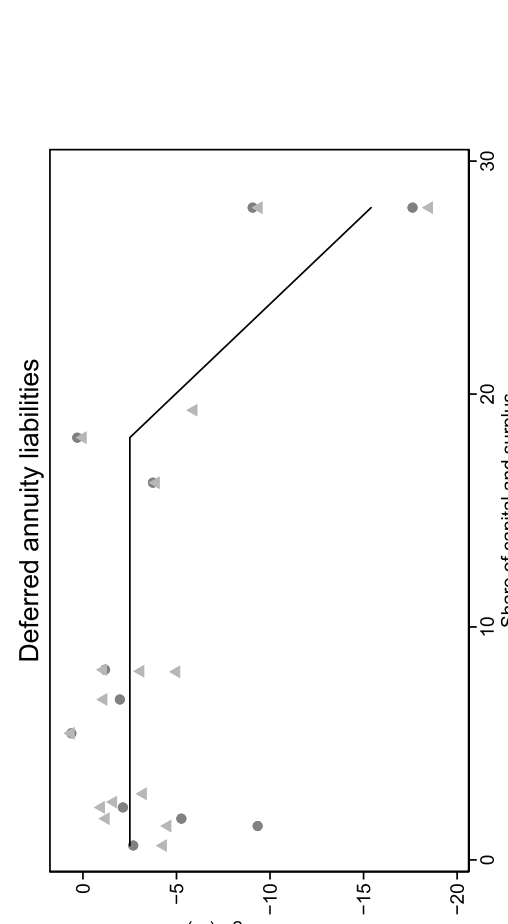

离离

పี

¿ हु

들 귱

उ

于实

늘

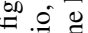

ค. 䒕

용.

$\pi$

잉

혼구 $\frac{0}{0}$ क

뭉

एक $\dot{0} \doteq$

휴웡

¿

范

क. .

흥무

일

茴坣吉

일

गี

क

- ํํㅇ

픙

듬ำ

(\%) әБиечว әэџฺd

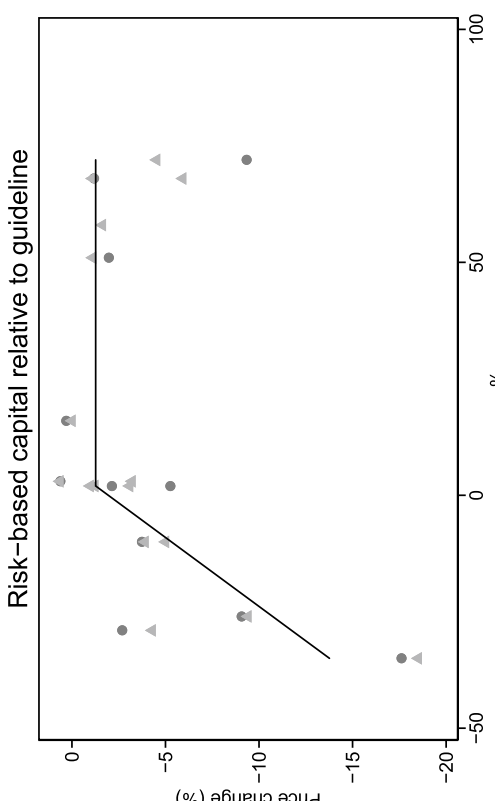

छ

ए)

这出

루

잉ㅇㅇㅇ

충

를

苍方

Z \&

금

용. 종

氺

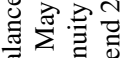
ฮี छ ? 叫 $\mathscr{d} \frac{0}{0}$ 전

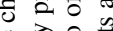

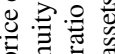

링

ฮี ส $\Xi$

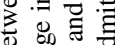
ี สิ 음 歾

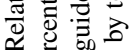
․ ํํㄴ료류 


\section{Conclusion}

The risk profile of life insurers has become increasingly complex and opaque over the last two decades because of variable annuities, derivatives, and reinsurance. Because life insurers are fundamentally in the business of financial engineering, financial engineering could play a central role in designing financial disclosure and prudential regulation. Life insurers could report risk measures by line of business such as life insurance, fixed annuities, and variable annuities. In particular, they could report duration and convexity for interest risk, delta and gamma for equity risk, and vega for volatility risk. Because many insurers are part of global insurance groups, insurers could report consolidated financial statements with sufficient detail regarding minimum return guarantees, derivatives, and reinsurance to be able to assess overall risk mismatch at the international level.

Standardized stress tests could be useful for monitoring potential risk mismatch and ensuring stability of the insurance sector. Stress tests could be reported at the level of operating companies, insurance groups, and state guaranty associations. Stress tests could focus on systematic financial risks such as interest risk, credit risk including a large-scale ratings migration, equity risk, and volatility risk. In addition, stress tests could consider changes in policyholder behavior such as a slowdown in lapsation and surrender rates in a prolonged period of low interest rates. Regulators could require insurers to hold more equity if the stress tests reveal fragility. The results of stress tests could be made public, at least at the level of state guaranty associations, to ensure market discipline.

More broadly, academics and policymakers could reassess the statutory accounting principles and risk-based capital regulation in light of the evolution from traditional insurance to financial engineering. Assets and liabilities could be reported at market value instead of statutory accounting value to increase transparency and to reduce incentives for insurers to not act in the best interests of policyholders. At the same time, regulators could use long-term risk measures (e.g., value-at-risk or expected equity shortfall), instead of short-term risk measures that are commonly used for other intermediaries such as banks. Long-term risk measures recognize the long-term nature of life insurer liabilities that are not prone to runs and would avoid procyclical behavior such as asset fire sales. Of course, measurement of longterm risk is challenging and potentially sensitive to reasonable variation in modeling assumptions. Developing a robust framework to ensure the stability of the insurance sector is an important task for academics and policymakers.

\section{Appendix 1: Variable definitions}

We define the following variables based on the Financial Accounts of the United States (Board of Governors of the Federal Reserve System 2017).

- Life insurers.

- Assets: FL544090005_Q. 
- Liabilities: FL544190005_Q - FL543194733_Q.

- Life insurance: FL543140005_Q.

- Annuities in the general account: FL543150005_Q.

- Pension funds: FL593095005_Q.

- Annuities in the separate account: LM543150085_Q.

- Property and casualty insurers.

- Assets: FL514090005_Q.

- Liabilities: FL514190005_Q - FL513194733_Q.

- Banks.

- Assets: FL704090005_Q.

- Liabilities: FL704190005_Q - FL763194735_Q - FL753194503_Q.

- Private defined contribution plans:

- Liabilities: FL574090055_Q.

- Private defined benefit plans.

- Liabilities: FL574190043_Q.

- Households.

- Net worth: FL154090005_Q - FL154190005_Q.

\section{References}

Allen, Franklin, and Douglas Gale. 1997. Financial Markets, Intermediaries, and Intertemporal Smoothing. Journal of Political Economy 105 (3): 523-546.

Ball, Laurence, and N. Gregory Mankiw. 2007. Intergenerational Risk Sharing in the Spirit of Arrow, Debreu, and Rawls, with Applications to Social Security Design. Journal of Political Economy 115 (4): 523-547.

Berends, Kyal, and Thomas B. King. 2015. Derivatives and Collateral at U.S. Life Insurers. Federal Reserve Bank of Chicago Economic Perspectives 39 (1): 21-37.

Board of Governors of the Federal Reserve System. 2017. Financial Accounts of the United States. No. Z.1 in Federal Reserve Statistical Release. Washington, DC: Board of Governors of the Federal Reserve System.

Chan, Yeung Lewis, and Leonid Kogan. 2002. Catching Up with the Joneses: Heterogeneous Preferences and the Dynamics of Asset Prices. Journal of Political Economy 110 (6): 1255-1285.

Credit Suisse. 2012. US Variable Annuities. Credit Suisse Connections Series.

Dumas, Bernard. 1989. Two-Person Dynamic Equilibrium in the Capital Market. Review of Financial Studies 2 (2): 157-188.

European Insurance and Occupational Pensions Authority. 2014. EIOPA Insurance Stress Test 2014. Working paper 14-203, EIOPA.

European Systemic Risk Board. 2015. Issues Note on Risks and Vulnerabilities in the EU Financial System. Working paper, European Systemic Risk Board.

Hartley, Daniel, Anna Paulson, and Richard J Rosen. 2017. Measuring Interest Rate Risk in the Life Insurance Sector: The U.S. and the U.K. In The Economics, Regulation, and Systemic Risk of Insurance Markets, Chap. 6, ed. Felix Hufeld, Ralph S .J. Koijen, and Christian Thimann, 124-150. Oxford: Oxford University Press. 
Hombert, Johan and Victor Lyonnet. 2017. Intergenerational Risk Sharing in Life Insurance: Evidence from France. Working paper, HEC Paris.

Junus, Novian and Zohair Motiwalla. 2009. A Discussion of Actuarial Guideline 43 for Variable Annuities. Milliman Research Report.

Kashyap, Anil K. 2002. Sorting Out Japan's Financial Crisis. Federal Reserve Bank of Chicago Economic Perspectives 26 (4): 42-55.

Koijen, Ralph S.J., and Motohiro Yogo. 2015. The Cost of Financial Frictions for Life Insurers. American Economic Review 105 (1): 445-475.

Koijen, Ralph S. J. and Motohiro Yogo. 2021. The Fragility of Market Risk Insurance. Journal of Finance, forthcoming.

Koijen, Ralph S.J., and Motohiro Yogo. 2022. Financial Economics of Insurance. Princeton: Princeton University Press.

Lee, Soon-Jae, David Mayers, and Clifford W Smith Jr. 1997. Guaranty Funds and Risk-Taking: Evidence from the Insurance Industry. Journal of Financial Economics 44 (1): 3-24.

MetLife Investors USA Insurance Company. 2008. MetLife Series VA Prospectus.

Paulson, Anna, Richard Rosen, Zain Mohey-Deen, and Robert McMenamin. 2012. How Liquid Are U.S. Life Insurance Liabilities? Chicago Fed Letter 302.

Roberts, Richard. 2012. Did Anyone Learn Anything from the Equitable Life? Lessons and Learning from Financial Crises. Working paper, King's College London.

Sen, Ishita. 2019. Regulatory Limits to Risk Management. Working paper, Harvard University.

Sun, Peter. 2009. The VA Industry: An Analysis of Recent Activities. Milliman Research Report.

Sun, Peter, Ken Mungan, Joshua Corrigan, and Gary Finkelstein. 2009. Performance of Insurance Company Hedging Programs during the Recent Capital Market Crisis. Milliman Research Report. 